\title{
KUALITAS TUNA KALENG DARI PERAIRAN ACEH YANG DISTERILISASI DENGAN PRESSURE CANNER
}

\author{
Quality of Canned Tuna from Aceh Water \\ Sterilized Using a Pressure Canner
}

\author{
Sri Haryani Anwar ${ }^{1 *}$, Rosa Wildatul Hifdha', Syarifah Rohaya', dan Hafidh Hasan ${ }^{1,2}$ \\ 'Jurusan Teknologi Hasil Pertanian, Fakultas Pertanian, Universitas Syiah Kuala, \\ Jl. Teuku Nyak Arief No.441, Kopelma Darussalam, Banda Aceh, 23111, Indonesia \\ 2Jurusan Teknik Elektro dan Komputer, Fakultas Teknik, Universitas Syiah Kuala, \\ Jl. Syekh Abdurauf As Sinkili No.7, Kopelma Darussalam, Banda Aceh, 23111, Indonesia \\ *Korespondensi penulis: sri.haryani@unsyiah.ac.id \\ Diterima: 21 Oktober 2020; Direvisi: 4 Mei 2021; Disetujui: 10 Juni 2021
}

\begin{abstract}
ABSTRAK
Ikan tuna termasuk komoditi yang mudah rusak sehingga perlu diolah untuk memperpanjang umur simpan, salah satu caranya dengan pengalengan. Penelitian tentang pengalengan tuna dari perairan Aceh belum pernah dilakukan. Oleh karena itu, penelitian ini bertujuan untuk mempelajari kualitas tuna kaleng yang disterilisasi menggunakan alat pressure canner berkapasitas $24 \mathrm{~L}$ dengan memvariasikan suhu dan lama sterilisasi (suhu $121^{\circ} \mathrm{C}$ selama 20 menit dan suhu $115^{\circ} \mathrm{C}$ selama 50 menit) serta jenis medium (larutan garam dan minyak kelapa sawit). Ikan tuna yang dikalengkan diperoleh dari perairan Aceh. Parameter kualitas bahan baku yang diuji pada tuna segar adalah kadar histamin, angka lempeng total (ALT), dan $\mathrm{pH}$. Sementara itu, parameter kualitas yang diuji pada tuna kaleng adalah ALT, $\mathrm{pH}$, kandungan logam berat (timbal dan merkuri), serta tingkat penerimaan konsumen melalui uji organoleptik (hedonik). Hasil penelitian menunjukkan bahwa ALT tuna kaleng pada semua perlakuan $<1 \times 10^{1}$ koloni $/ g$, sedangkan kandungan timbal $(\mathrm{Pb})<0,0001$ $\mathrm{mg} / \mathrm{kg}$, dan merkuri $(\mathrm{Hg})$ berkisar antara 0,29-0,58 $\mathrm{mg} / \mathrm{kg}$. Hasil uji hedonik menunjukkan bahwa panelis secara umum dapat menerima kedua jenis produk tuna kaleng, namun panelis lebih menyukai rasa tuna kaleng dalam larutan garam serta warna tuna kaleng dalam minyak kelapa sawit. Hasil penelitian ini menyarankan pengalengan tuna sebaiknya dilakukan pada suhu $121^{\circ} \mathrm{C}$ selama 20 menit.
\end{abstract}

KATA KUNCI : tuna kaleng, sterilisasi, cemaran mikroba, cemaran logam, histamin

\begin{abstract}
Tuna is a perishable commodity thus it needs to be preserved to prolong its shelf life. The Canning process is one of the solutions to increase tuna shelf life at room temperature. Research on the tuna canning processes from Aceh waters has never been reported. Therefore, this research aimed to investigate the quality of canned tuna which was sterilized using a $24 \mathrm{~L}$ pressure canner with varying the temperature and duration of sterilization $\left(121^{\circ} \mathrm{C}\right.$ for 20 minutes and $115^{\circ} \mathrm{C}$ for 50 minutes) and the type of medium (brine and palm oil). The fresh tuna used for canning was caught from Aceh water. The quality parameters evaluated for fresh tuna were histamine levels, total plate count (TPC), and $\mathrm{pH}$. Meanwhile, the parameters tested on the quality of the canned tuna were TPC, $\mathrm{pH}$ value, heavy metals lead $(\mathrm{Pb})$ and mercury $(\mathrm{Hg})$ contamination, and levels of consumer acceptance through organoleptic tests (hedonic). The results indicated that the TPC values for all canned tuna were $<1 \times 10^{1} \mathrm{cfu} / \mathrm{g}$, the metal contaminations were $<0.0001 \mathrm{mg} / \mathrm{kg}$ for $\mathrm{Pb}$, and in the range of $0.29-0.58 \mathrm{mg} / \mathrm{kg}$ for $\mathrm{Hg}$. The hedonic tests proved that although all the panelists accepted these two types of canned tuna, they prefer the taste of canned tuna in a salt solution and the color of canned tuna in palm oil. This research suggests that the sterilization process for canned tuna using a $24 \mathrm{~L}$ pressure canner should be carried out at $121^{\circ} \mathrm{C}$ for $20 \mathrm{~min}$.
\end{abstract}

KEYWORDS: canned tuna, sterilization, microbial activity, heavy metal contamination, histamine

\section{PENDAHULUAN}

Indonesia memiliki wilayah perairan laut yang luas dengan garis pantai sekitar $81.000 \mathrm{~km}$ dan mendapat hak pengelolaan serta pemanfaatan ikan $\pm 2,7$ juta $\mathrm{km}^{2}$ di Zona Ekonomi Ekslusif (ZEE). Hal ini menjadikan Indonesia sebagai salah satu negara penghasil ikan yang besar (Ghufran \& Kordi, 2010). Salah satu wilayah penghasil ikan terbesar di Indonesia adalah Provinsi Aceh. Potensi hasil laut 
Aceh sangat menjanjikan, namun hasil tangkapan yang cukup melimpah belum dapat meningkatkan perekonomian nelayan. Salah satu cara yang dapat dilakukan untuk meningkatkan nilai jual ikan adalah pengolahan ikan melalui proses pengalengan, namun hingga saat ini belum ada industri pengalengan dengan bahan baku ikan segar di Aceh.

Pengalengan merupakan salah satu cara pengawetan makanan yang melibatkan proses thermal atau yang lazim disebut dengan proses sterilisasi yang bertujuan untuk membunuh mikroba patogen dan pembusuk. Produk pengalengan dikemas secara hermetis agar aman, bergizi, dan stabil disimpan pada suhu ruang (Lewis, 2006). Proses sterilisasi pada pengalengan makanan umumnya dilakukan pada suhu $121^{\circ} \mathrm{C}$ dalam waktu tertentu tergantung pada produk, jenis, ukuran, dan dimensi kaleng (Fellows, 2017). Warne (1988) menyarankan dua kombinasi suhu dan waktu sterilisasi untuk pengalengan ikan, yaitu suhu $121,1^{\circ} \mathrm{C}$ selama $40,55,85$ atau 190 menit dan pada suhu $115,6^{\circ} \mathrm{C}$ selama $65,75,100$ atau 230 menit, tergantung pada dimensi kaleng, khususnya diameter dan tinggi kaleng. Misalnya, untuk kaleng dengan diameter $66 \mathrm{~mm}$ dan tinggi $40 \mathrm{~mm}$, disarankan sterilisasi pada suhu $115,6^{\circ} \mathrm{C}$ selama 65 menit atau pada suhu $121,1^{\circ} \mathrm{C}$ selama 40 menit. Irianto dan Akbarsyah (2007) menggunakan berbagai kombinasi suhu dan waktu sterilisasi pada pengalengan tuna komersial. Contohnya, kaleng berukuran $603 \times 408$ $(157,2 \times 177,8 \mathrm{~mm})$ untuk produk solid/chunk tuna in brine dapat dilakukan sterilisasi pada suhu 110, 113, atau $116^{\circ} \mathrm{C}$ dengan waktu 121,94 , atau 78 menit. Lamanya proses sterilisasi juga ditentukan oleh ukuran potongan daging ikan yang dikalengkan dan medium yang digunakan.

Proses pengalengan ikan biasanya menggunakan medium larutan perendam yang berfungsi sebagai penghantar panas, pengawet, penambah derajat keasaman, dan pemberi cita rasa pada produk akhir (Fellows, 2017). Pengalengan tuna biasanya menggunakan medium larutan garam dan minyak nabati sehingga produk yang dihasilkan berupa tuna in brine dan tuna in oil. Kajian yang dilakukan oleh Xavier, Gopinathan, Bindu, dan Gopal (2015) mengenai pengaruh medium larutan garam, saus tomat, kari, dan minyak (groundnut oil) terhadap penetrasi panas pada tuna kaleng menunjukkan bahwa penetrasi panas sangat di pengaruhi oleh jenis medium. Medium yang memberikan penetrasi panas paling cepat pada tuna adalah larutan garam, kemudian kari, saus tomat, dan minyak.

Faktor yang mempengaruhi proses pengalengan tuna sangat banyak. Pada penelitian ini, kegiatan difokuskan pada sterilisasi menggunakan pressure canner skala 24L. Jenis ikan tuna yang dikalengkan adalah yellowfin tuna (Thunnus albacares) yang ditangkap dari perairan Aceh. Kualitas tuna kaleng dievaluasi melalui parameter cemaran mikroba, $\mathrm{pH}$, kandungan logam (timbal dan merkuri), serta penerimaan konsumen. Kapasitas alat yang digunakan pada penelitian ini berbeda dengan kapasitas alat pada proses pengalengan pada umumnya dan dipilih agar proses transfer teknologi dari hasil penelitian ini kepada industri kecil, khususnya di Provinsi Aceh menjadi lebih mudah dan feasible.

\section{BAHAN DAN METODE}

\section{Bahan}

Bahan utama yang digunakan dalam penelitian ini adalah ikan tuna sirip kuning atau yellowfin tuna (Thunnus albacares) dengan berat $49 \mathrm{~kg}$ yang diperoleh dari Pelabuhan Pendaratan Samudera (PPS) Lampulo, Banda Aceh. Bahan tambahan untuk medium adalah minyak kelapa sawit dan larutan garam. Selain itu juga digunakan bahan-bahan untuk analisis berupa Plate Count Agar (PCA), Peptone Water Buffered, aquades, dan bahan uji organoleptik. Kaleng yang digunakan adalah three-piece cans dengan enamel bagian dalam berwarna kuning keemasan dengan diameter $7,3 \mathrm{~cm}$ dan tinggi $5,6 \mathrm{~cm}$ dengan total volume $234,26 \mathrm{~cm}^{3}$.

\section{Metode}

Perlakuan sterilisasi selama proses pengalengan meliputi kombinasi proses sterilisasi antara suhu $121^{\circ} \mathrm{C}$ selama 20 menit $\left(\mathrm{S}_{1}\right)$ dan suhu $115^{\circ} \mathrm{C}$ selama 50 menit $\left(S_{2}\right)$; serta jenis medium yang digunakan, yaitu larutan garam $\left(\mathrm{M}_{1}\right)$ dan minyak kelapa sawit $\left(\mathrm{M}_{2}\right)$. Pemilihan kedua kombinasi suhu dan waktu sterilisasi ini mengacu pada Manual on Fish Canning dan Thermal Processing (Warne, 1988; Lewis, 2006). Penelitian ini untuk membuktikan kondisi sterilisasi dengan alat pressure canner kapasitas 24L (tipe 92525 Quart, All American - USA). Evaluasi terhadap kualitas tuna kaleng meliputi uji mikrobiologi (ALT), cemaran logam timbal $(\mathrm{Pb})$ dan merkuri $(\mathrm{Hg})$, serta uji organoleptik (hedonik). Pengujian pada parameter tersebut diulang sebanyak 3 (tiga) kali.

\section{Persiapan pengalengan (Lewis,2006; Warne, 1988)}

Tahap pertama, sampel daging dari beberapa bagian tubuh ikan tuna diambil untuk pengujian 
histamin dan ALT. Selanjutnya, tuna segar disiangi untuk membuang sisik, kulit, kepala, insang, sirip, jeroan, dan bagian lain yang tidak diperlukan. Daging ikan tuna selanjutnya dipotong-potong dalam ukuran besar (loins) dan langsung dibekukan dalam freezer $\left(-20^{\circ} \mathrm{C}\right)$ sebelum disiapkan untuk proses pengalengan.

Pada saat proses pengalengan, loin tuna beku dikeluarkan dari freezer dan dibiarkan pada suhu ruang dalam wadah tertutup untuk proses thawing sampai semua es mencair. Loin kemudian dipotong-potong menjadi filet dan dicuci dengan air mengalir. Filet disusun pada rak stainless steel dengan dasar berlubang untuk proses pre-cooking secara steaming (uap air panas) pada suhu $80^{\circ} \mathrm{C}$ selama 15 menit menggunakan pengukus stainless steel kemudian didinginkan pada suhu ruang.

Filet tuna dibersihkan dan dipotong untuk memisahkan tulang dari daging ikan serta memisahkan daging yang berwarna gelap. Proses ini bertujuan untuk mendapatkan bentuk dan ukuran potongan daging ikan yang sesuai dengan ukuran kaleng yang digunakan. Tahap ini menghasilkan potongan ikan solid, potongan agak besar (chunk) dan potongan kecil, atau serpihan (flake). Pada penelitian ini digunakan daging dengan potongan chunk dan flake.

Wadah kaleng yang akan digunakan dibersihkan dan diperiksa untuk menghindari adanya karat atau cacat lainnya, seperti penyok atau deformasi bentuk kaleng. Kaleng kemudian dicuci dengan air sabun hangat, dibilas dengan air bersih dan dikeringkan.

\section{Pengisian (filling), exhausting dan seaming}

Pengisian kaleng dilakukan secara teratur dan seragam, yaitu daging ikan ditimbang sebanyak $80 \mathrm{~g}$ dan diisi ke dalam kaleng. Potongan daging ikan terdiri atas chunk yang tidak boleh kurang dari $1,2 \mathrm{~cm}$ dan flake yang berukuran kurang dari 1,2 cm (BSN, 2016). Kaleng yang sudah berisi potongan daging ikan ditambah medium sebanyak $80 \mathrm{~mL}$. Pada penelitian ini digunakan dua jenis medium yaitu larutan garam $5 \%$ dan minyak kelapa sawit. Pengisian medium sesuai batas head space atau $2 \mathrm{~cm}$ dari permukaan kaleng (Wisconsin Aluminum Foundry-USA, 2019).

Proses selanjutnya adalah exhausting, yaitu kaleng disusun di dalam penangas air (pengukus) pada suhu $80^{\circ} \mathrm{C}$ selama 10 menit. Proses ini dilakukan untuk mengeluarkan udara yang ada di dalam kaleng (head space) agar tidak terjadi perubahan warna, kontaminasi, dan memperkecil terjadinya korosi pada kaleng. Kaleng kemudian ditutup dengan semitro can seamer. Proses penutupan kaleng dilakukan secepat mungkin agar suhu bahan di dalam kaleng tidak menjadi terlalu rendah (Wisconsin Aluminum FoundryUSA, 2019).

\section{Sterilisasi dan pendinginan (Lewis, 2006; Warne, 1988)}

Sterilisasi dilakukan menggunakan alat pressure canner dengan kombinasi suhu dan waktu, yaitu $115^{\circ} \mathrm{C}$ selama 50 menit dan $121^{\circ} \mathrm{C}$ selama 20 menit. Tuna kaleng didinginkan sesegera mungkin setelah proses sterilisasi. Pendinginan dilakukan dengan merendam kaleng di dalam air bersih pada suhu ruang selama \pm 30 menit. Kaleng lalu dikeringkan dengan dibiarkan di ruang terbuka selama \pm 24 jam. Tahap pendinginan merupakan proses yang penting untuk mencegah over cooking atau over proces.

\section{Analisis Bahan Baku dan Ikan Tuna Kaleng}

Analisis bahan baku ikan tuna segar (sebelum pengalengan) meliputi kadar histamin dengan metode Amperometric Enzymatic Biosensor-Biofish Biolan (Salleres et al., 2016), pH, dan ALT (ISO 4833:2003 (E), ISO 7218:2012). Analisis yang dilakukan pada tuna kaleng adalah uji ALT (ISO 4833:2003 (E), ISO 7218:2012), cemaran logam timbal (Pb) (MU/MO/10AAS) dan merkuri (Hg) (MU/MO/12-AAS), serta uji organoleptik (hedonik). Limit atau batasan untuk uji histamin (tuna segar), ALT, cemaran logam (Pb dan $\mathrm{Hg}$ ) dari tuna mengacu pada SNI 8223:2016 (BSN, 2016).

Uji hedonik terhadap produk tuna kaleng melibatkan 30 panelis semi terlatih. Panelis menilai sampel berdasarkan kesukaan yang meliputi empat atribut yaitu rasa, warna, aroma, dan tekstur. Skor penilaian yang digunakan adalah $1=$ Sangat tidak suka, $2=$ Tidak suka, $3=$ Netral, $4=$ Suka, dan $5=$ Sangat suka.

\section{Pengolahan Data}

Penelitian ini menggunakan Rancangan Acak Kelompok (RAK) pola faktorial yang terdiri atas 2 faktor. Faktor pertama adalah dua kondisi sterilisasi (S), yaitu $S_{1}=121^{\circ} \mathrm{C}$ dan 20 menit dan $S_{2}=115^{\circ} \mathrm{C}$ dan 50 menit. Faktor kedua adalah dua jenis medium (M), yaitu $\mathrm{M}_{1}=$ larutan garam, $\mathrm{M}_{2}=$ minyak kelapa sawit. Perlakuan dilakukan sebanyak 3 kali ulangan. Data dianalisis secara statistik menggunakan analysis of variance (ANOVA) dengan software Microsoft Excel 2016 untuk mengetahui adanya perbedaan antar pelakuan. Uji lanjut dilakukan menggunakan uji beda nyata terkecil (BNT) untuk mengetahui perlakuan terbaik. 


\section{HASIL DAN PEMBAHASAN}

\section{Kualitas Bahan Baku}

\section{Kadar histamin tuna segar}

Histamin $\left(\mathrm{C}_{5} \mathrm{H}_{9} \mathrm{~N}_{3}\right)$ adalah senyawa amina biogenik yang dihasilkan dari aktivitas enzim histidin dekarbosilase oleh mikroorganisme penghasil histamin (histamine producing bacteria) pada daging ikan skromboid termasuk tuna atau bahan makanan lainnya karena adanya kandungan histidin. Proses ini umumnya muncul akibat dari proses pengolahan atau penyimpanan yang tidak menerapkan sistem rantai dingin (Rachmawati, 2018). Histamin juga dikenal sebagai scrombotoxin dan dapat terbentuk jika ikan kelompok skromboid (khususnya tuna dan makarel) disimpan pada suhu di atas $4^{\circ} \mathrm{C}$ pada waktu yang lama. Penanganan pembekuan dan pendinginan yang tidak tepat dapat meningkatkan kadar histamin secara cepat. Kadar histamin yang diperbolehkan pada tuna adalah < 50 ppm (Garcia-Tapia et al., 2013).

Hasil pengujian kandungan histamin pada daging tuna segar menunjukkan kadar histamin yang cukup rendah yaitu $4 \mathrm{mg} / \mathrm{kg}$ atau $4 \mathrm{ppm}$. Berdasarkan SNI 2729:2013 (BSN, 2013a) tentang ikan segar, kandungan histamin pada ikan segar sebelum diolah maksimal $100 \mathrm{mg} / \mathrm{kg}$ atau $100 \mathrm{ppm}$. Kadar histamin ikan tuna segar pada penelitian ini lebih rendah dibandingkan dengan penelitian Mohan, Remya, Murthy, Ravishankar, dan Kumar (2015), yaitu 8,17 ppm. Menurut Lehane dan Olley (1999), kandungan histamin pada ikan dipengaruhi oleh kadar histidin, bakteri penghasil enzim dekarboksilase, dan kondisi lingkungan. Kandungan histamin juga dipengaruhi oleh spesies ikan, suhu, waktu, dan kondisi penyimpanan.

Hasil pengujian bahan baku menjadi dasar bagi kelanjutanan proses pengalengan. Jika kadar histamin ikan segar melebihi ambang batas yang diizinkan, maka proses pengalengan tidak dapat diteruskan. Kadar histamin tuna segar sebesar 4 ppm membuktikan bahwa tuna yang digunakan memenuhi syarat awal bahan baku. Hasil yang diperoleh cukup rendah dan masih jauh di bawah standar keamanan pangan yang ditetapkan sehingga masih aman untuk dikonsumsi dan layak untuk digunakan sebagai bahan baku tuna kaleng.

\section{Analisis angka lempeng total (ALT) tuna segar}

Ikan merupakan salah satu komoditi pangan yang cepat rusak (perishable) diakibatkan oleh aktifitas enzim dan mikroorganisme karena tingginya kandungan air dan protein. Jumlah mikroba pada suatu bahan pangan dapat mempengaruhi cepat atau lambatnya kerusakan bahan pangan tersebut. Ikan yang akan diolah atau dikonsumsi harus memiliki kualitas yang baik dan aman. Hasil pengujian Angka Lempeng Total (ALT) menjadi salah satu indikator atau standar tingkat kesegaran ikan (BSN, 2013a; BSN, 2014).

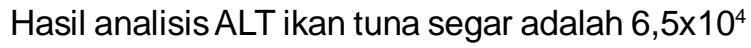
koloni/g. Menurut SNI 2729:2013 (BSN, 2013a) dan SNI 4110:2014 (BSN, 2014), cemaran mikroba pada

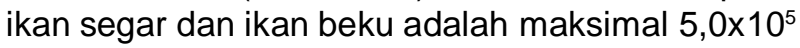
koloni/g. Hasil uji ALT pada penelitian ini masih di bawah standar yang telah ditetapkan sehingga masih aman dan memenuhi syarat untuk dikonsumsi atau dikalengkan. Jumlah kandungan mikroba pada ikan dipengaruhi oleh penanganan setelah penangkapan atau pemanenan. Menurut Affandi, Ferasyi, dan Karina (2016) cemaran mikroba dapat dihambat dengan cara penanganan khusus pada ikan setelah ditangkap dan diturunkan dari kapal nelayan dengan pemberian es curah agar ikan tetap dalam keadaan baik dan memperlambat proses pembusukannya.

\section{$\mathrm{pH}$}

Nilai $\mathrm{pH}$ merupakan salah satu kriteria yang menjadi penentu kualitas ikan segar. Ada dua kategori nilai $\mathrm{pH}$ ikan, yaitu $\mathrm{pH}<7$ termasuk ikan yang masih sangat segar, sedangkan $\mathrm{pH}>7$ termasuk ke dalam ikan yang telah mengalami perubahan kesegaran menuju pembusukan (Metusalach, Kasmiati, \& Jaya 2014). Hasil uji pH terhadap ikan tuna segar pada penelitian ini sebesar 5,97. Menurut hasil penelitian Metusalach et al. (2014), nilai pH 5,61-6,39 menunjukkan bahwa ikan hasil tangkapan masih berkualitas baik.

Nilai pH ikan pada penelitian ini tidak jauh berbeda dengan $\mathrm{pH}$ tuna loin segar pada hasil penelitian Suryaningrum, Ikasari, dan Octavini (2017) yang berkisar 5,96-6,13. Nilai pH ikan ketika masih hidup biasanya mendekati 7 , namun setelah kematian menjadi berkisar 6-7. Hal ini tergantung dari proses penangkapan, musim, kondisi biologi, dan cara mematikan ikan (Suryaningrum et al., 2017). Berdasarkan hasil pengukuran tiga parameter (histamin, ALT, dan $\mathrm{pH}$ ) yang dilakukan terhadap tuna segar hasil tangkapan dari perairan Aceh, maka dapat disimpukan bahwa tuna tersebut layak untuk diolah lebih lanjut, termasuk sebagai bahan baku ikan kaleng.

\section{Kualitas Tuna Kaleng}

$\mathrm{pH}$

Hasil analisis data secara statistik menunjukkan bahwa kondisi sterilisasi (S), jenis medium (M) dan 
interaksi keduanya (SM) tidak berpengaruh nyata $(p>0,05)$ terhadap nilai $\mathrm{pH}$ ikan tuna kaleng. Nilai $\mathrm{pH}$ pada ikan tuna kaleng secara keseluruhan berkisar antara 5,85 sampai 6,02 dengan nilai rata-rata 5,91 (Tabel 1). Nilai $\mathrm{pH}$ tuna kaleng yang diperoleh berada pada kisaran $\mathrm{pH}$ tuna kaleng yang dilaporkan oleh Elshehawy dan Farag (2019), yaitu 5,6-5,82. Namun, nilai $\mathrm{pH}$ rata-rata tuna kaleng pada penelitian ini $(5,91)$ mengalami sedikit penurunan bila dibandingkan $\mathrm{pH}$ ikan tuna segar $(5,97)$.

Penurunan nilai $\mathrm{pH}$ ikan kaleng dibandingkan dengan $\mathrm{pH}$ bahan baku juga dilaporkan oleh beberapa penelitian terdahulu. Pada hasil penelitian Murda, Husni, Budhiyanti, dan Herwati (2016), diperoleh penurunan nilai $\mathrm{pH}$ ikan lele dumbo asap berbumbu dalam kaleng yang disebabkan karena proses pemanasan menggunakan asap cair. Asap cair yang digunakan memiliki pH rendah $\leq 4,0$. Bawinto, Mongi, dan Kaseger (2015) menjelaskan bahwa perubahan nilai $\mathrm{pH}$ pada suatu produk dapat dipengaruhi oleh faktor lama penyimpanan dan komposisi produk yang dikalengkan. Selain itu, lamanya waktu sterilisasi yang berbeda juga dapat menyebabkan perbedaan nilai $\mathrm{pH}$ pada produk. Penggunaan suhu sterilisasi yang tinggi dilaporkan juga dapat menyebabkan penurunan nilai $\mathrm{pH}$ (Jannah, Handayani, Dipokusumo, \& Werdiningsih, 2018). Penelitian Reza et al. (2015) melaporkan penurunan $\mathrm{pH}$ ikan chela setelah pengalengan menjadi 5,9 dari nilai $\mathrm{pH}$ ikan segar sebesar 6,8. Beberapa hasil penelitian juga melaporkan peningkatan $\mathrm{pH}$ ikan kaleng (Lahamy \& Mohamed, 2020), sehingga dapat disimpulkan bahwa perubahan nilai $\mathrm{pH}$ ikan setelah dikalengkan dipengaruhi oleh banyak faktor.

\section{Cemaran logam ( $\mathrm{Pb}$ dan $\mathrm{Hg})$}

Hasil uji kandungan timbal $(\mathrm{Pb})$ ikan tuna kaleng pada semua perlakuan $<0,0001 \mathrm{mg} / \mathrm{kg}$ (Tabel 1 ). Menurut Badan Standardisasi Nasional Indonesia (2016) kandungan $\mathrm{Pb}$ pada ikan dan olahannya maksimal $0,3 \mathrm{mg} / \mathrm{kg}$. Hasil tersebut menunjukkan bahwa kandungan $\mathrm{Pb}$ pada ikan tuna kaleng masih jauh dari syarat yang telah ditentukan dan aman dari cemaran $\mathrm{Pb}$. Sementara itu, hasil uji kandungan $\mathrm{Hg}$ menunjukkan antara $0,13 \mathrm{mg} / \mathrm{kg}$ sampai $0,80 \mathrm{mg} / \mathrm{kg}$ (Tabel 1) dengan rata-rata $0,40 \mathrm{mg} / \mathrm{kg}$. Hasil tersebut masih memenuhi syarat yang ditentukan untuk cemaran logam $\mathrm{Hg}$ pada ikan kaleng menurut BSN (2016), yaitu maksimum $1,0 \mathrm{mg} / \mathrm{kg}$. Hasil analisis data secara statistik menunjukkan bahwa kondisi sterilisasi $(\mathrm{S})$, jenis medium (M) dan interaksi dari keduanya (SM) tidak berpengaruh nyata $(p>0,05)$ terhadap kandungan $\mathrm{Pb}$ dan merkuri Hg ikan tuna kaleng.

\section{Angka lempeng total (ALT)}

Pengujian ALT menunjukkan bahwa ikan tuna yang disterilisasi dalam proses pengalengan pada penelitian ini telah memenuhi pesyaratan SNI 8223:2016 (BSN, 2016) tentang tuna dalam kemasan kaleng dan SNI 2712:2013 (BSN, 2013b) tentang ikan dalam kemasan kaleng hasil sterilisasi. Nilai cemaran mikroba pada ikan kaleng menunjukkan tingkat keberhasilan proses sterilisasi dan menjadi penentu kelayakan produk tersebut untuk dikonsumsi. Hasil uji ALT pada sterilisasi suhu $121^{\circ} \mathrm{C}$ selama 20 menit menunjukkan tidak ada mikroba yang tumbuh (Tabel 2). Hal tersebut juga dilaporkan oleh Kaba, Corapci, Eryasar, dan Karabek (2014) dalam penelitiannya yang

Tabel 1. Hasil pengujian $\mathrm{pH}$ dan cemaran logam tuna kaleng

Table 1. Results of $\mathrm{pH}$ measurement and metal contamination analysis of canned tuna

\begin{tabular}{cccc}
\hline Sampel/Samples & $\mathbf{p H}$ & $\begin{array}{c}\text { Cemaran logam Pb/ } \\
\text { Pb contamination }(\mathrm{mg} / \mathbf{k g})\end{array}$ & $\begin{array}{c}\text { Cemaran logam } \mathrm{Hg} / \\
\boldsymbol{H g} \text { contamination }(\mathbf{m g} / \mathbf{k g})\end{array}$ \\
\hline $\mathrm{S}_{1} \mathrm{M}_{1}$ & $5.90 \pm 0.058^{\mathrm{a}}$ & $<0.0001^{\mathrm{a}}$ & $0.29 \pm 0.164^{\mathrm{a}}$ \\
$\mathrm{S}_{1} \mathrm{M}_{2}$ & $5.94 \pm 0.068^{\mathrm{a}}$ & $<0.0001^{\mathrm{a}}$ & $0.58 \pm 0.247^{\mathrm{a}}$ \\
$\mathrm{S}_{2} \mathrm{M}_{1}$ & $5.88 \pm 0.026^{\mathrm{a}}$ & $<0.0001^{\mathrm{a}}$ & $0.35 \pm 0.042^{\mathrm{a}}$ \\
$\mathrm{S}_{2} \mathrm{M}_{2}$ & $5.92 \pm 0.051^{\mathrm{a}}$ & $<0.0001^{\mathrm{a}}$ & $0.39 \pm 0.045^{\mathrm{a}}$ \\
\hline
\end{tabular}

Keterangan/Notes:

Angka dengan superskrip yang berbeda pada kolom yang sama adalah berbeda nyata $(p<0,05)$ / Numbers in the same column followed by different superscripts are significantly different $(p<0.05)$

$\mathrm{S}_{1}=$ Sterilisasi pada $121^{\circ} \mathrm{C}, 20 \mathrm{menit} /$ Sterilization at $121^{\circ} \mathrm{C}, 20 \mathrm{~min}$

$\mathrm{S}_{2}=$ Sterilisasi pada $115^{\circ} \mathrm{C}, 50 \mathrm{menit} /$ Sterilization at $115^{\circ} \mathrm{C}, 50 \mathrm{~min}$

$\mathrm{M}_{1}=$ Larutan garam/Brine

$\mathrm{M}_{2}=$ Minyak kelapa sawit/Palm oil 
Tabel 2. Hasil uji Total Plate Count sampel tuna kaleng Table 2. Results of Total Plate Count of canned tuna

\begin{tabular}{clcc}
\hline No & \multicolumn{1}{c}{ Sampel/Samples } & & $\begin{array}{c}\text { Total Plate Count (koloni/g)/ } \\
\text { (cfu/g) }\end{array}$ \\
\hline 1 & $\begin{array}{l}\text { Tuna kaleng dalam larutan garam } \\
\text { sterilisasi } 121^{\circ} \mathrm{C}, 20 \text { menit)/Canned tuna } \\
\text { in brine }\left(\text { sterilized at } 121^{\circ} \mathrm{C}, 20 \text { min) }\right.\end{array}$ \\
$2 \quad \begin{array}{l}\text { Tuna kaleng dalam minyak kelapa sawit } \\
\text { (sterilisasi } 121^{\circ} \mathrm{C}, 20 \text { menit)/Canned tuna } \\
\text { in palm oil }\left(\text { Sterilized at } 121^{\circ} \mathrm{C}, 20 \text { min) }\right.\end{array}$ & $\mathrm{S}_{1} \mathrm{M}_{1}$ & 0 \\
$3 \quad \begin{array}{l}\text { Tuna kaleng dalam larutan garam } \\
\text { (sterilisasi } 115^{\circ} \mathrm{C}, 50 \text { menit)/Canned tuna } \\
\text { in brine }\left(\text { sterilized at } 115^{\circ} \mathrm{C}, 50 \text { min) }\right.\end{array}$ & $\mathrm{S}_{1} \mathrm{M}_{2}$ & 0 \\
$4 \quad \begin{array}{l}\text { Tuna kaleng dalam minyak kelapa sawit } \\
\text { (sterilisasi } 115^{\circ} \mathrm{C}, 50 \text { menit)/Canned tuna } \\
\text { in palm oil (sterilized at } 115^{\circ} \mathrm{C}, 50 \text { min) }\end{array}$ & $\mathrm{S}_{2} \mathrm{M}_{1}$ & $<1 \times 10^{1}$ \\
\hline
\end{tabular}

menunjukkan tidak ada mikroba yang tumbuh pada telur ikan asap kaleng yang disterilisasi pada suhu $121^{\circ} \mathrm{C}$ selama 15 menit. Sementara itu, uji ALT pada suhu sterilisasi $115^{\circ} \mathrm{C}$ selama 50 menit menunjukkan total mikroba $<1 \times 10^{1}$ koloni $/ \mathrm{g}$.

Batas cemaran mikroba pada ikan kaleng menurut SNI 2712:2013 (BSN, 2013b) adalah maksimal $<1 \times 10^{1} \mathrm{koloni} / \mathrm{g}$. Dengan demikian dapat disimpulkan bahwa batas cemaran mikroba pada penelitian ini sesuai dengan standar SNI. Hal ini juga dapat membuktikan bahwa proses sterilisasi yang dilakukan pada kedua kombinasi suhu dan waktu sterilisasi telah memenuhi syarat SNI yang ditunjukkan dengan jumlah kandungan mikroba pada produk akhir yang jauh lebih kecil dibandingkan dengan bahan baku ikan segar. Selain proses sterilisasi, tahapan proses pengalengan yaitu proses pre-cooking dan exhausting dapat mengurangi pertumbuhan bakteri (Fellows, 2017). Pre-cooking juga bertujuan untuk mengurangi kadar air dan menginaktifasi enzim serta memudahkan pemisahan atau pemotongan daging ikan (Warne, 1988).

Berdasarkan hasil pengujian ALT, cemaran logam dan nilai $\mathrm{pH}$ tuna kaleng, maka dapat disimpulkan bahwa tuna kaleng yang dihasilkan telah memenuhi syarat SNI. Hal ini berlaku untuk perlakuan tuna kaleng dalam larutan garam maupun dalam minyak kelapa sawit. Ketiga parameter uji tersebut berada dalam kisaran standar SNI 2712:2013 (BSN,2013b). Hasil ini juga membuktikan bahwa proses sterilisasi menggunakan pressure canner dengan kapasitas 24 L pada dua kombinasi suhu dan waktu sterilisasi dapat menghasilkan produk yang aman untuk dikonsumsi.

\section{Uji Organoleptik (Hedonik) Ikan Tuna Kaleng}

\section{Warna}

Salah satu unsur yang menentukan mutu suatu produk pangan adalah atribut warna. Warna menjadi salah satu faktor yang mendapat perhatian lebih dari konsumen karena warna memberi kesan apakah komoditi pangan tersebut akan disukai atau tidak. Warna juga mempunyai peranan penting sebagai daya tarik, tanda pengenal dan atribut mutu (Tarwendah, 2017).

Warna ikan tuna segar berbeda dengan tuna yang telah disterilisasi. Tuna segar berwarna merah gelap sedangkan tuna yang telah disterilisasi berwarna putih pucat. Hal tersebut dapat disebabkan oleh proses thermal seperti yang dilaporkan oleh Rodríguez, Carriles, dan Aubourg (2010) pada penelitiannya tentang pengalengan ikan salmon. Warna merah dari ikan salmon segar mengalami penurunan dan menjadi putih pucat. Ikan tuna yang telah melalui pengolahan panas akan berwarna lebih terang dibandingkan tuna mentah atau tuna segar.

Dari hasil penelitian ini diperoleh nilai organoleptik warna tuna kaleng 3,10-3,87 (netral-suka) dengan nilai rata-rata 3,48 (netral). Analisis data secara statistik menunjukkan bahwa hanya jenis medium $(M)$ yang berpengaruh nyata $(p<0,05)$ terhadap organoleptik warna tuna kaleng. Panelis lebih menyukai ikan tuna kaleng dengan medium minyak kelapa sawit.

Pada Gambar 1 dapat dilihat bahwa warna tuna kaleng dengan medium minyak kelapa sawit lebih disukai oleh panelis dibandingkan dengan warna tuna 


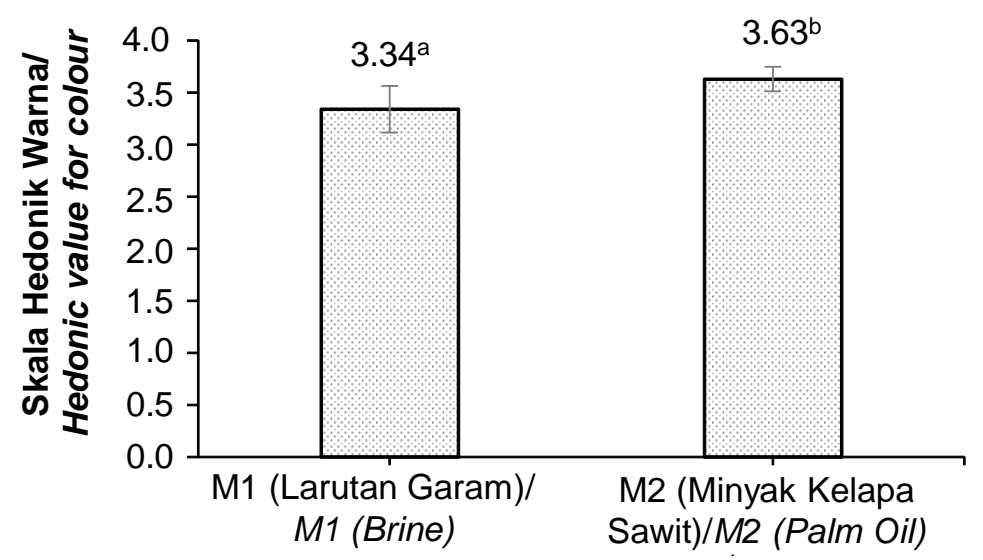

Jenis Medium/Type of Medium

Gambar 1. Pengaruh perbedaan medium (M) terhadap nilai organoleptik warna ikan tuna kaleng (Nilai dengan tanda huruf yang berbeda menunjukkan perbedaan yang nyata $(p<0,05))$

Figure 1. Effect of different medium $(M)$ toward hedonic value for colour of canned tuna (Numbers denote with different alphabet showed significant differences $(p<0,05))$

dalam larutan garam. Perbandingan warna dari kedua jenis medium tersebut jauh berbeda. Minyak kelapa sawit berwarna kuning keemasan dan lebih menarik jika dibandingkan dengan larutan garam yang berwarna bening. Hal tersebut mungkin menjadi alasan bagi para panelis untuk lebih menyukai tuna kaleng dalam minyak kepala sawit.

Hasil penelitian Thaiyibah (2016) menunjukkan bahwa tuna kaleng dengan penambahan minyak atsiri jahe dengan konsentrasi tertinggi (15\%) lebih disukai panelis karena memiliki warna kuning terang. Kondisi yang sama juga dilaporkan peneliti lainnya dimana ikan mas India (catla) kaleng dalam minyak memiliki skor tertinggi terhadap nilai penampakan dibandingkan ikan mas kaleng dalam brine, saus tomat, dan kari (Das, Dora, \& Mishra, 2007).

\section{Aroma}

Indikator lain dalam uji organoleptik adalah aroma yang merupakan bau dari suatu produk pangan (Tarwendah, 2017). Hasil uji hedonik pada aroma tuna kaleng menunjukkan bahwa tingkat kesukaan panelis terhadap aroma tuna kaleng adalah 2,97-3,80 (netral - suka) dengan nilai rata-rata 3,34 (netral). Nilai ratarata tertinggi diperoleh dari tuna kaleng dengan kondisi sterilisasi pada suhu $121^{\circ} \mathrm{C}$ selama 20 menit dengan medium larutan garam, yaitu 3,52 (suka).

Nilai rata-rata terendah diperoleh untuk produk tuna kaleng yang disterilisasi pada suhu $115^{\circ} \mathrm{C}$ selama 50 menit dengan medium larutan garam, yaitu 3,09 (netral). Namun demikian, analisis data secara statistik menunjukkan bahwa semua perlakuan tidak berpengaruh nyata $(p>0,05)$ terhadap nilai organoleptik aroma tuna kaleng. Hal ini sesuai dengan hasil akhir, yaitu tuna kaleng dari berbagai perlakuan menunjukkan tingkat aroma yang hampir sama, sehingga panelis cenderung memberi skor netral. Menurut SNI 8223:2016 (BSN, 2016), bau tuna kaleng yang baik adalah beraroma khas ikan kaleng, yaitu seperti aroma ikan asap.

\section{Rasa}

Rasa merupakan salah satu sifat atau atribut mutu dari organoleptik yang berupa persepsi pada indera pencecap di dalam mulut yang meliputi cita rasa asin, masam, pahit, manis, dan umami (Setyaningsih et al., 2010). Data uji organoleptik rasa ikan tuna kaleng menunjukkan bahwa tingkat kesukaan panelis terhadap rasa ikan tuna kaleng adalah 2,90-3,50 (netral) dengan nilai rata-rata 3,18 (netral). Hasil analisis statistik menunjukkan hanya jenis medium yang berpengaruh nyata $(p \leq 0,05)$ terhadap nilai organoleptik rasa tuna kaleng.

Gambar 2 menunjukkan bahwa rasa tuna kaleng dalam Iarutan garam lebih disukai panelis dibandingkan dengan rasa tuna dalam minyak kelapa sawit. Hal tersebut mungkin disebabkan adanya rasa asin yang berasal dari larutan garam sementara tuna dalam minyak tidak memiliki rasa atau hambar. Penelitian Das et al. (2007) mengenai ikan catla yang dikalengkan dengan medium larutan garam dan minyak memiliki skor hedonik rasa yang tidak terlalu berbeda. Pada penelitian ini, panelis cenderung memilih kriteria netral karena ikan kaleng yang diuji belum melalui masa simpan dan belum mengalami perubahan komposisi kimia dan reaksi enzimatis, 


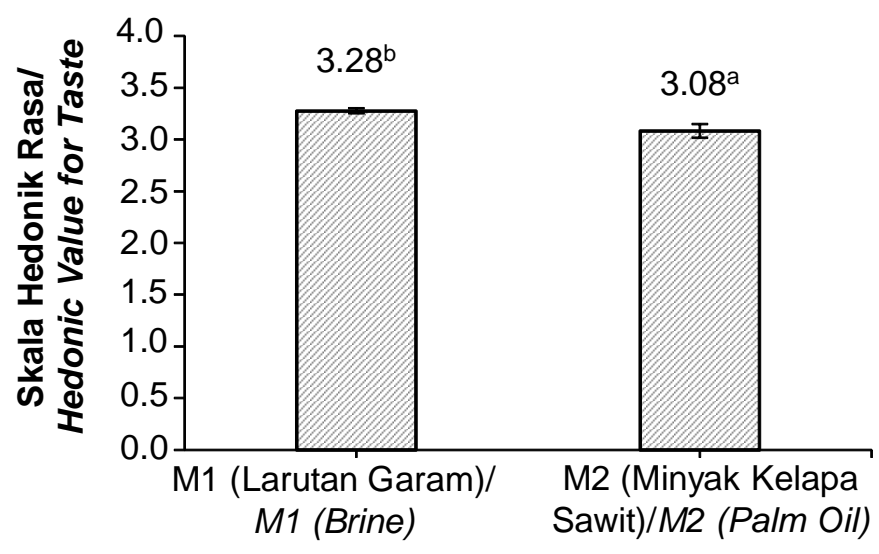

Jenis Medium/Type of Medium

Gambar 2. Pengaruh jenis medium (M) terhadap organoleptik rasa tuna kaleng (Nilai yang diikuti dengan huruf yang berbeda menunjukkan perbedaan yang nyata $(p<0,05))$

Figure 2. Effect of medium type $(M)$ toward hedonic value of taste for canned tuna (Numbers denote with different alphabet showed significant differences $(p<0,05))$

sehingga rasa daging ikan kaleng belum mengalami perubahan yang signifikan. Thaiyibah (2016) melaporkan bahwa nilai hedonik rasa ikan tuna kaleng tanpa penyimpanan cenderung memiliki skor netral dan semakin menurun sehubungan dengan lamanya masa penyimpanan. Penurunan rasa pada suatu bahan pangan dapat disebabkan oleh penguraian lemak, protein dan karbohidrat melalui proses kimiawi yang terjadi akibat reaksi enzimatis (Hadiwiyoto, 1993).

\section{Tekstur}

Tekstur merupakan sifat fisik dari suatu bahan yang dapat dirasakan oleh indera perasa (lidah) dan peraba (kulit). Hasil uji organoleptik menunjukkan bahwa tingkat kesukaan panelis terhadap tekstur ikan tuna kaleng adalah 3,37-3,87 (netral-suka) dengan nilai ratarata 3,61 (suka). Secara statistik, semua variabel penelitian tidak berpengaruh nyata terhadap nilai tekstur ikan tuna kaleng. Hal tersebut mungkin disebabkan oleh tekstur ikan kaleng yang dihasilkan dinilai hampir sama sehingga panelis cenderung memilih nilai netral untuk tekstur ikan tuna. Das et al. (2007) juga melaporkan dalam penelitiannya bahwa penilaian panelis terhadap nilai tekstur ikan catla yang dikalengkan tidak jauh berbeda antara ikan dalam minyak dan larutan garam.

\section{KESIMPULAN}

Produk tuna kaleng yang berasal dari perairan Aceh pada penelitian ini telah memenuhi syarat SNI jika dilihat dari evaluasi produk secara mikrobiologi, tingkat cemaran logam, dan tingkat penerimaan panelis melalui uji hedonik. Kandungan logam $\mathrm{Hg}$ dan $\mathrm{Pb}$ tuna kaleng masih jauh di bawah standar SNI 8223:2016. Penurunan terjadi pada total mikroba dari $6,5 \times 10^{4}$ koloni/g pada tuna segar menjadi $<1 \times 10^{1} \mathrm{koloni} / \mathrm{g}$ pada tuna kaleng yang disterilisasi pada suhu $115^{\circ} \mathrm{C}$ selama 50 menit, bahkan tidak ada koloni yang tumbuh pada sterilisasi $121^{\circ} \mathrm{C}$ selama 20 menit. Hal ini membuktikan bahwa produk tuna kaleng dalam larutan garam dan minyak kelapa sawit ini telah memenuhi standar SNI 2712:2013 tentang ikan dalam kemasan kaleng hasil sterilisasi dan SNI 8223:2016 tentang tuna dalam kemasan kaleng. Berdasarkan evaluasi total mikroba dan cemaran logam pada produk akhir, penelitian ini menyarankan kondisi sterilisasi lebih baik dilakukan pada kombinasi suhu $121^{\circ} \mathrm{C}$ selama 20 menit. Hasil uji organoleptik menunjukkan panelis lebih menyukai rasa tuna kaleng dalam larutan garam namun lebih menyukai warna tuna kaleng dalam minyak kelapa sawit. Skor yang diberikan panelis untuk aroma dan tekstur tuna kaleng tidak berbeda secara signifikan.

\section{UCAPAN TERIMA KASIH}

Penulis mengucapkan terima kasih kepada Universitas Syiah Kuala yang telah mendanai penelitian ini melalui Skim Penelitian Unggulan Universitas Syiah Kuala-PNBP tahun anggaran 2018.

\section{DAFTAR PUSTAKA}

Affandi, R. P., Ferasyi, T. R., \& Karina, S. (2016). Uji mikrobiologi ikan tongkol (Euthynnus affinis) yang 
didistribusikan di tempat pelelangan ikan (TPI) Lampulo dan oleh pedagang ikan keliling (PIK) di Kota Banda Aceh. Jurnal IImiah Mahasiswa Kelautan Perikanan Unsyiah, 1(3).

Badan Standarisasi Nasional (BSN). 2013a. SNI 2729:2013: Ikan Segar. BSN: Jakarta

Badan Standardisasi Nasional Indonesia (BSN). 2013b. SNI 2712:2013: Ikan dalam kemasan kaleng hasil sterilisasi. BSN: Jakarta.

Badan Standardisasi Nasional (BSN). (2014). SNI 4110:2014: Ikan Beku. BSN: Jakarta.

Badan Standardisasi Nasional (BSN). (2016). SNI 8223:2016: Tuna dalam kemasan kaleng. BSN: Jakarta.

Bawinto, A. S., Mongi, E., \& Kaseger, B. E. (2015). Analisa Kadar Air, pH, Organoleptik, dan Kapang pada Produk Ikan Tuna (Thunnus sp.) Asap, di Kelurahan Girian Bawah, Kota Bitung, Sulawesi Utara. Jurnal Media Teknologi Hasil Perikanan, 3(2), 55-65. doi: 10.35800/mthp.3.2.2015.10355.

Das, N., Dora, K. C., \& Mishra, R. (2007). Development of canned products from Indian major carp, catla (Catla catla). Bangladesh Journal of Fisheries Research, 11(2), 223-228.

EIShehawy, S. M., \& Farag, Z. S. (2019). Safety assessment of some imported canned fish using chemical, microbiological and sensory methods. The Egyptian Journal of Aquatic Research, 45(4), 389394. doi : 10.1016/j.ejar.2019.08.005

Fellows, P. (2017). Food Processing Technology: Principle and Practice (4th ed.). United Kingdom: Woodhead Publishing.

García-Tapia, G., Barba-Quintero, G., Gallegos-Infante, J. A., Aguilar, R. P., Ruíz-Cortés, J. A., \& Ramírez, J. A. (2013). Influence of physical damage and freezing on histamine concentration and microbiological quality of yellowfin tuna during processing. Food Science and Technology, 33(3), 463-467. doi: 10.1590/S0101-20612013005000061

Ghufran, M. H., \& Kordi, K. (2010). Budi Daya Perairan ( $1^{\text {st }}$ ed.). Bandung, Indonesia: Citra Aditya Bakti.

Hadiwiyoto, S. 1993. Teknologi Pengolahan Hasil Perikanan. Yogyakarta: Liberty.

Irianto, H. E., \& Akbarsyah, T. M. I. (2007). Pengalengan ikan tuna komersial. Squalen Bulletin of Marine and Fisheries Postharvest and Biotechnology, 2(2), 43-50.

Jannah, M., Handayani, B. R., Dipokusumo, B., \& Werdiningsih, W. (2018). Peningkatan mutu dan daya simpan ikan pindang kuning "pindang rumbuk" dengan perlakuan lama sterilisasi. Pro Food, 4(1), 311-323. doi:10.29303/profood.v4i1.80

Kaba, N., Corapci, B., Eryasar, K., \& Karabek, H. N. (2014). Sensory, Chemical and Microbiological Characteristics of Canned-Smoked Whiting Roe Pate. Arastirma, 38(5), 259-266. doi:10.5505/gida.2013.35229

Lahamy, A. A. E. \& Mohamed, H.R., (2020). Changes in Fish Quality During Canning Process and Storage Period of Canned Fish Products: Review Article. Global Journal of Nutrition \& Food Science, 3(1), 1-7. doi : $10.33552 / G J N F S .2020 .03 .000553$
Lehane, L., \& Olley, J. (1999). Histamine (Scombroid) fish poisoning: A review in a risk-assessment framework. Canberra, Australia: Animal Health Science and Emergency Management Branch, National Office of Animal and Plant Health.

Lewis, M.J. (2006). Thermal Processing. In: J.G. Brennan, ed. Food Processing Handbook. WileyBlackwell.pp.33-70

Metusalach, M., Kasmiati, K., \& Jaya, I. (2014). Pengaruh cara penangkapan, fasilitas penangan dan cara penanganan ikan terhadap kualitas ikan yang dihasilkan. Jurnal Ipteks Pemanfaatan Sumberdaya Perikanan, 1(1), 40-52. doi:10.20956/ jipsp.v1i1.59.

Mohan, C. O., Remya, S., Murthy, L. N., Ravishankar, C. N., \& Kumar, K. A. (2015). Effect of filling medium on cooking time and quality of canned yellowfin tuna (Thunnus albacares). Food Control, 50, 320-327. doi:10.1016/j.foodcont.2014.08.030

Murda, Y. K., Husni, A., Budhiyanti, S. A., \& Herwati, E. R. N. (2016). Karakteristik kimia dan mikrobiologi filet lele dumbo asap berbumbu dalam kaleng. Jurnal Pengolahan Hasil Perikanan Indonesia, 19(2), 140147. doi:10.17844/jphpi.2016.19.2.140

Rachmawati, N., (2018). Assessing the risk of histamine from the Indonesian salted-boiled fish (pindang). Doctoral dissertation. University of Tasmania, Australia

Reza, S., Karmaker, S., Hasan, M., Roy, S., Hoque, R., \& Rahman, N. (2015). Effect of traditional fish processing methods on the proximate and microbiological characteristics of Laubuka dadiburjori during storage at room temperature. Journal of Fisheries and Aquatic Science, 10(4), 232. doi: 10.3923/jfas.2015.232.243

Rodríguez, A., Carriles, N., \& Aubourg, S. P. (2010). Effect of chill storage under different icing conditions on sensory and physical properties of canned farmed salmon (Oncorhynchus kisutch). International Journal of Food Science \& Technology, 45(2), 295-304. doi:10.1111/j.13652621.2009.02135.x

Salleres, S., González, I., Arantzamendi, A., González, R., Maza, S., Jaureguibeitia, A., ... \& Benner, R. A. (2016). Validation of the biofish-300 HIS enzymatic biosensor for the detection of histamine in fishery products. Journal of AOAC International, 99(5), 1338-1355. doi: 10.5740/jaoacint.16-0180

Setyaningsih, D., Apriyantono, A., \& Sari, M. P. (2014). Analisis sensori untuk industri pangan dan argo. PT Penerbit IPB Press: Bogor.

Suryaningrum, T. D., Ikasari, D., \& Octavini, H. (2017). Evaluasi mutu tuna loin segar untuk sashimi yang diolah di atas perahu selama penanganan dan distribusinya di Ambon. Jurnal Pascapanen Dan Bioteknologi Kelautan Dan Perikanan, 12(2), 163178. doi:10.15578/jpbkp.v12i2.329

Tarwendah, I. P. (2017). Studi komparasi Atribut Sensoris dan Kesadaran Merek Produk Pangan. Jurnal Pangan dan Agroindustri, 5(2), 66-73. 
Thaiyibah, R. (2016). Pengaruh penambahan natrium benzoat dan minyak atsiri jahe (Zingiber officinale) sebagai bahan pengawet terhadap kualitas ikan tuna (Thunnus sp.) kaleng. Skripsi. Universitas Syiah Kuala.

Warne, D. (1988). Manual on fish canning - 1. Principles of canning. FAO Fisheries Technical Paper - 285 Food and Agriculture Organization of the United Nations.
Wisconsin Aluminum Foundry-USA. (2019). Instructions and Recipes of All American Pressure Cooker/ Canner

Xavier, K. A. M., Gopinathan, S. P., Bindu, J., \& Gopal, T. K. S. (2015). Effect of filling media on heat penetration characteristics and texture of skipjack Tuna (Katsuwonis pelamis) in indigenous polymer coated easy open-end tin free steel cans. Journal Fishery Technology, 44(2), 159-166. 